\title{
International conservation volunteering from the UK: what does it contribute?
}

\begin{abstract}
Increasing numbers of fee-paying volunteers now travel from the UK to work on conservation projects in middle and low income countries. The time and resources they commit have important implications for international conservation practice. This article provides an overview of this sector, comprising data on its size, value and key organizations. I map the scope of volunteer-led conservation in 2007 in terms of the countries, species and habitats prioritized for attention, and identify distinct geographical and taxonomic partialities towards particular taxa, countries and habitats. I outline how conservation priorities are established and reflect on two factors that help account for the identified partialities: the history and politics of international conservation and the cultural preferences of volunteers. In conclusion I argue that volunteering can help international conservation but is not a panacea for comprehensive efforts to protect threatened biodiversity.
\end{abstract}

Keywords Conservation priorities, ecotourism, flagship species, history of conservation, volunteering.

This paper contains supplementary material that can be found online at http://journals.cambridge.org

\section{Introduction}

$\mathrm{N}$ inety percent of conservation funding originates and is spent in economically rich countries (Brooks et al., 2006). The remaining $10 \%$ includes the small amounts of money raised in poor nations and the geographically flexible resources that flow from rich to poor countries under the auspices of multilateral agencies, bilateral aid agreements and non-governmental transactions. International non-governmental organizations have come to account for an increasing percentage of these resources over the last decade as government and multilateral investment in conservation has declined by c. $50 \%$ (Rodriguez et al., 2007). Geographically flexible flows of resources exert disproportionate influence on global conservation and determine the priorities, the quality and the quantity of work undertaken.

International volunteering is a geographically flexible mechanism for funding conservation that has experienced growth in the last 20 years. However, to date there has been

JAmie Lorimer Department of Geography, Kings College London, Strand, WC2R 2LS, UK. E-mail jamie.lorimer@kcl.ac.uk

Received 4 December 2007. Revision requested 11 January 2008. Accepted 7 April 2008. little systematic research that explores the history, character, scope and significance of this sector in relation to its impacts on conservation. This article begins to address this gap. Focusing on volunteers leaving the UK, it provides a brief history of the sector, a typology of its key organizations, and an estimate of their size and value. I then map the geographical and taxonomic scope of volunteer conservation, identify distinct spatial and ecological patterns of prioritization, and reflect on the degree to which these overlap with threatened biodiversity. The article then identifies some of the underlying causes of partialities in volunteering.

International conservation volunteers can be defined as those people who travel from their home country to help support wildlife conservation, research and rehabilitation projects, both in situ and ex situ. Most existing studies of conservation volunteering can be found in tourism studies. These tend to take a case study approach and are concerned with the motives of volunteers (Caissie \& Halpenny, 2003; Galley \& Clifton, 2004; Campbell \& Smith, 2006), their characteristics (Weiler \& Richins, 1995; Broad, 2003) and the impacts of their participation (Clifton \& Benson, 2006). Conservation biologists have considered and defended the quality of the data produced by volunteers (Newman et al., 2003). In descriptive work that draws on similar empirical material to this paper, Cousins (2007) summarized the geographical and taxonomic scope of the conservation tourism sector and its different modus operandi.

There is now an extensive body of work in conservation biology and the social sciences on the history of international conservation (Adams, 2003), the post-colonial politics of its activities (Adams \& Mulligan, 2002; Brockington, 2002; Rodriguez et al., 2007), the efficacy and scope of its operations (Brooks et al., 2006; Cleary, 2006) and its consequences for the future of biodiversity (Bowker, 2004). I draw on and develop several of the themes that run though this literature.

\section{Methods}

This study employed a mix of qualitative and quantitative methods to gather data from a sample of UK-based organizations offering international conservation volunteering opportunities. The two main methods used were a review of the organizations' online and published literatures and semi-structured interviews with the managers of volunteer programmes. These were carried out in the summer of 2007. 
A sample of 23 organizations was selected for analysis. This includes the 15 largest operators (sending $>100$ conservation volunteers to $>_{1}$ country per annum) and eight smaller operators, selected to represent different taxa, geographical regions and modus operandi. Together the sample accounts for $>90 \%$ of all volunteers working overseas with UK-registered organizations.

All of the volunteering organizations advertise their programmes online and through an annual brochure. These documents provide overview information on each operator, including the total number of programmes run, the countries in which they operate, the taxa and habitats on which they focus and in which they take place, and the cost and duration of volunteer participation. These data were gathered for each operator and added to a database, which comprised entries for each of the 342 volunteer programmes offered in July 2007. Conservation programmes within the UK were excluded because of the international focus of this investigation. Organizations market particular destinations and programmes through brochures and web pages and this material was collected for textual analysis.

Semi-structured interviews were arranged with senior representatives of the 23 organizations. Eleven of these were carried out face-to-face and the remainder were conducted over the telephone. Interviewees were asked to corroborate the gathered data and further information was requested on the numbers of fee-paying volunteers recruited and staff employed in the UK. Key questions remained consistent between interviews (Appendix) but the schedule was tailored to address the specific characteristics of the organization under investigation. Face-to-face interviews were recorded and transcribed. Notes were taken during telephone interviews.

The additional quantitative data were inserted into the database. As some programmes are supplied by more than one organization the dataset was examined for double entries and 18 programmes were excluded, leaving a total of 324 . Data were not available on the number of volunteers attending each individual programme. Instead it was necessary to divide the total number of volunteers with each organization by the number of projects they offer. This assumes that volunteers with an organization are equally spread across all programmes. This may not necessarily be the case but in the circumstances this provided the best means for weighting each programme for the subsequent statistical analysis of geographical and taxonomic patterns.

The interview transcripts and notes, organizational literature and relevant recent press coverage of the sector were coded and analysed using NVivo v. 8 (QSR International, Southport, UK), a software tool that assists qualitative data analysis. This process helped identify common themes, experiences and explanations within this material that could be identified and explored to produce grounded theoretical explanations.

\section{Results}

\section{Overview}

The formal history of overseas conservation volunteering from the UK begins in the mid 1980 s when the first organized programmes for fee-paying members of the public were established. Prior to this the British Schools Exploring Society had been organizing expeditions for young people since the 1930s, and the British Trust for Conservation Volunteers (formerly The Conservation Corps) had been recruiting volunteers from 1959 for work in the UK. The early pioneers in the sector were US-based Earthwatch (now the Earthwatch Institute), who opened their European branch in 1984, Coral Cay Conservation (founded 1986) and the Society for Environmental Exploration (now Frontier; 1989). These charitable or non-profit organizations emphasize the scientific basis of their projects, which they largely run themselves.

As Table 1 shows, there was a steady flow of new organizations starting up throughout the 1990 os and into the 21st century. Several of the more recently founded organizations, such as Global Vision International, i-to-i and Travellers Worldwide, are private companies offering a wide range of volunteering opportunities of which conservation projects are just a subset. These commercial organizations now recruit more volunteers than the older non-profit organizations. Their main concern is to source and look after volunteers for conservation programmes provided and managed by local businesses or NGOs.

Although there are little numerical data available it is known that the number of people volunteering on conservation projects has increased dramatically since the early 1980 . This can be linked to the growing popularity of the pre- and post-university so-called gap year, growing numbers of active retirees and the broader enthusiasm for volunteering in UK society as a whole (Low et al., 2007). In 2006-2007 12,195 fee-paying volunteers were posted to overseas conservation projects by the organizations represented in this study. They were employed on 324 programmes in 75 different countries.

The duration of the volunteering programmes varies by organization and individual: from 2 weeks to 5 months, with an average for the sample of 4.6 weeks. The price or contribution paid by each volunteer also varies from GBP 225 per week with i-to-i and Real Gap to GBP 750 per week with Earthwatch and Biosphere Expeditions. The average total contribution for each volunteer was GBP 1,450. The total income from conservation volunteers for these UK organizations in 2006-2007 was c. GBP 17.27 million. Volunteers also provided nearly 57,000 weeks of unpaid labour.

Because of commercial and brand sensitivities, the lack of collective accounting standards and the diversity of 
TABLE 1 Overview data for 23 organizations in the UK conservation volunteering sector.

\begin{tabular}{|c|c|c|c|c|c|c|c|c|c|c|c|}
\hline Organization & Status & Founded & $\begin{array}{l}\text { No. of } \\
\text { countries }\end{array}$ & $\begin{array}{l}\text { No. of } \\
\text { projects }\end{array}$ & $\begin{array}{l}\text { Total } \\
\text { volunteers } \\
(2006-2007)\end{array}$ & $\begin{array}{l}\text { Conservation } \\
\text { volunteers } \\
(2006-2007) \\
\end{array}$ & $\begin{array}{l}\text { UK } \\
\text { staff }\end{array}$ & $\begin{array}{l}\text { Average } \\
\text { volunteer } \\
\text { duration } \\
\text { (weeks) }\end{array}$ & $\begin{array}{l}\text { Total } \\
\text { volunteer } \\
\text { weeks }\end{array}$ & $\begin{array}{l}\text { Average } \\
\text { volunteer } \\
\text { contribution (GBP) }\end{array}$ & $\begin{array}{l}\text { Total income } \\
\text { from volunteers } \\
\text { (GBP K) }\end{array}$ \\
\hline $\begin{array}{l}\text { British Schools } \\
\text { Exploring Society }\end{array}$ & Charity & 1932 & 5 & 5 & 167 & 167 & 7 & 6 & 1,002 & 2,000 & 334 \\
\hline $\begin{array}{l}\text { British Trust for } \\
\text { Conservation Volunteers }\end{array}$ & Company \& charity & 1959 & 16 & 16 & 215 & 215 & 4 & 2 & 430 & 600 & 129 \\
\hline Scientific Exploration Society & Charity & 1969 & 2 & 2 & 65 & 65 & 1 & 5 & 325 & 2,400 & 156 \\
\hline Operation Raleigh & Charity & 1984 & 4 & 4 & 700 & 700 & 27 & 7 & 4,900 & 2,250 & 1,575 \\
\hline Earthwatch Europe & Company \& charity & 1984 & 34 & 88 & 650 & 650 & 50 & 2 & 1,300 & 1,300 & 845 \\
\hline Coral Cay & Non-profit with trust & 1986 & 3 & 4 & 200 & 200 & 8 & 6 & 1,200 & 2,260 & 452 \\
\hline Frontier & Non-profit & 1989 & 12 & 22 & $\dagger$ & $\dagger$ & 65 & 4 & 2,600 & 1,200 & $\dagger$ \\
\hline Trekforce & Charity & 1990 & 3 & 3 & 60 & 60 & 5 & 20 & 1,200 & 3,500 & 210 \\
\hline Orangutan Foundation & Charity & 1991 & 1 & 1 & 48 & 48 & 5 & 6 & 288 & 550 & 26 \\
\hline i-to-i & Company with trust & 1992 & 20 & 38 & 6,500 & 1,950 & 40 & 4 & 7,800 & 900 & 1,755 \\
\hline Teaching \& Projects Abroad & Company & 1992 & 7 & 7 & 3,500 & 500 & 18 & 8 & 4,000 & 2,000 & 1,000 \\
\hline Travellers Worldwide & Company & 1994 & 8 & 20 & $\dagger$ & 300 & 14 & 8 & 2,400 & 1,600 & 480 \\
\hline Operation Wallacea & Company with trust & 1995 & 6 & 10 & 1,600 & 1,600 & 20 & 4 & 6,400 & 1,750 & 2,800 \\
\hline Worldwide Experience & Company & 1995 & 4 & 10 & 275 & 275 & 4 & 4 & 1,100 & 2,400 & 660 \\
\hline Pioneer Madagascar & Charity & 1995 & 1 & 1 & 60 & 60 & 1.5 & 10 & 600 & 2,000 & 120 \\
\hline Quest Overseas & Company with trust & 1996 & 8 & 9 & 275 & 275 & 6 & 5 & 1,375 & 1,500 & 413 \\
\hline Greenforce & Non-profit & 1997 & 5 & 6 & 350 & 245 & 7 & 8 & 1,960 & 2,000 & 490 \\
\hline Global Vision International & Company with trust & 1999 & 17 & 22 & 1,750 & 925 & 15 & 5 & 4,625 & 1,600 & 1,480 \\
\hline Biosphere Expeditions & Company & 1999 & 9 & 9 & 400 & 400 & 16 & 2 & 800 & 1,300 & 520 \\
\hline Outreach International & Company with trust & 1999 & 5 & 10 & 115 & 40 & 2 & 14 & 560 & 3,000 & 120 \\
\hline $\begin{array}{l}\text { Real GAP/GAP } \\
\text { Year for Grown Ups }\end{array}$ & Company & 2000 & 21 & 45 & 7,500 & 3,000 & 40 & 4 & 12,000 & 900 & 2,700 \\
\hline $\begin{array}{l}\text { African Conservation } \\
\text { Experience }\end{array}$ & Company & 2001 & 2 & 9 & $\dagger$ & $\dagger$ & 4 & 8 & 2,560 & 3,800 & $\dagger$ \\
\hline Blue Ventures & Non-profit with trust & 2001 & 1 & 1 & 120 & $120^{\star}$ & $\mathrm{n} / \mathrm{a}$ & 6 & 720 & 1,765 & 212 \\
\hline Averages per volunteer & & & & & & & & 4.71 & & 1,450 & \\
\hline Total & & & 75 & 324 & 26,520 & 12,765 & 359.5 & & 60,145 & & $18,472.7$ \\
\hline
\end{tabular}

${ }^{*}$ Data from Cousins (2007)

$\dagger$ Non-disclosure requested 
TABLE 2 The taxonomic distribution of species-specific conservation programmes and volunteers on these programmes.

\begin{tabular}{lcc}
\hline Taxon & $\begin{array}{l}\text { Total no. } \\
\text { (\% of total) }\end{array}$ & $\begin{array}{l}\text { Total no. of } \\
\text { volunteers } \\
\text { (\% of total) }\end{array}$ \\
\hline Mammals & $132(68)$ & $4,086(64)$ \\
Big five* & $33(17)$ & $1,165(18)$ \\
Herbivores & $22(11)$ & $658(10)$ \\
Other & $8(4)$ & $137(2)$ \\
Carnivores & $29(15)$ & $882(14)$ \\
Felines & $17(9)$ & $631(10)$ \\
Primates & $25(13)$ & $816(13)$ \\
Cetaceans & $17(9)$ & $428(7)$ \\
Herpetofauna & $21(11)$ & $836(13)$ \\
Turtles & $17(9)$ & $763(12)$ \\
Fish & $5(3)$ & $307(5)$ \\
Sharks & $4(2)$ & $256(4)$ \\
Birds & $8(4)$ & $86(1)$ \\
Invertebrates & $4(2)$ & $26(0.4)$ \\
Caterpillars/Butterflies & $3(1.6)$ & $19(0.3)$ \\
Plants & $2(1)$ & $13(0.2)$ \\
General rehabilitation & $22(11)$ & $988(15)$ \\
\hline
\end{tabular}

*White and black rhino Ceratotherium simum and Diceros bicornis, African elephant Loxodonta africana, buffalo Syncerus caffer, lion Panthera leo and leopard Panthera pardus

business models involved (Table 1) it was difficult to identify and quantify how much of this GBP 17.27 million actually went towards conservation. From my fieldwork in Sri Lanka, published papers and recent examples reported in the popular press it is clear that the proportion of funds going directly to conservation and the quality of the work being carried out varies greatly between different organizations and programmes (Clifton \& Benson, 2006; VSO, 2007). I do not intend here to judge the efficacy of the sector overall or to arbitrate between different operators, although these are important concerns requiring further research.

\section{The taxonomy of international conservation} volunteer programmes

Of the 324 programmes examined 130 were focused on habitat conservation and 194 were targeted at specific species or taxa. Of the taxon-specific programmes 56 took place ex situ and were largely concerned with rehabilitation and captive breeding. Although there were more taxonspecific programmes in total they attracted only slightly more volunteers $(6,385)$ than habitat-specific programmes $(5,815)$.

Within the taxon-specific programmes strong partialities are expressed towards mammals ( $68 \%$ of programmes and $64 \%$ of volunteers) over all other groups (Table 2). Furthermore, certain taxa are clearly prioritized. The socalled big five (white and black rhino Ceratotherium simum and Diceros bicornis, African elephant Loxodonta africana, buffalo Syncerus caffer, lion Panthera leo and leopard Panthera pardus), other carnivores, primates, turtles, other herbivores and cetaceans are the most popular targets for conservation programmes and their volunteers. The most popular single species is the lion, which is the target of 10 different programmes.

Approximately $58 \%$ of volunteers on species specific programmes worked to conserve threatened species (categorized on the IUCN Red List as Critically Endangered (20\%), Endangered (11\%) or Vulnerable (27\%; IUCN, 2007)).

\section{Biogeography of volunteering}

Table 3 shows the biogeographical division of the habitatspecific volunteer programmes according to the percentage of volunteers they receive. Tropical forests (37\%) and coral reefs $(20 \%)$ are the most popular biogeographical zones. Considering the geography of all volunteering programmes, both habitat and taxon-specific, then tropical forests $(27 \%)$ and savannah type habitats $(23 \%)$ are the most popular. Climatically, volunteer projects are clustered in tropical countries, which attract $73 \%$ of volunteers and $66 \%$ of projects.

Table 4 shows the proportion of in situ projects and their volunteers that are located within priority zones for global conservation, as established by three of the most well known templates for assessing vulnerability (Brooks et al., 2006): Conservation Hotspots (Myers et al., 2000), Critical Ecoregions (Hoekstra et al., 2005) and Megadiversity countries (Mittermeier, 1997). Overall, $84 \%$ of in situ projects, accommodating $86 \%$ of volunteers, were located in regions subject to at least one form of priority designation. However, there are some clear spatial partialities. For example, certain hotspots, such as Mesoamerica, Sundaland and the Tropical Andes, are especially well visited, whereas the Guinean Forests

TABLE 3 The biogeographical distribution of conservation programmes, with the total for habitat-specific programmes and the combined total for all programmes (habitat and speciesspecific).

\begin{tabular}{lcc}
\hline Habitat & $\begin{array}{l}\text { Total no. } \\
\text { (\% of total) }\end{array}$ & $\begin{array}{l}\text { Combined total } \\
\text { no. } \% \text { of total) }\end{array}$ \\
\hline Mountain & $118(2)$ & $207(2)$ \\
Freshwater & $123(2)$ & $191(2)$ \\
Other & $164(3)$ & $367(3)$ \\
Polar & $175(3)$ & $175(1)$ \\
Coastal & $339(6)$ & $1,218(10)$ \\
Arid & $245(4)$ & $565(5)$ \\
Marine & $381(7)$ & $945(8)$ \\
Savannah & $444(8)$ & $2,808(23)$ \\
Temperate & $481(8)$ & $1,231(10)$ \\
Coral reef & $1,160(20)$ & $1,166(10)$ \\
Tropical forest & $2,184(37)$ & $3,327(27)$ \\
\hline
\end{tabular}


TABLE 4 Number of in situ volunteering projects and volunteers in global conservation priority zones.

\begin{tabular}{lll}
\hline Designation & $\begin{array}{l}\text { Total no. of programmes } \\
\text { (\% of total) }\end{array}$ & $\begin{array}{l}\text { Total no. of volunteers } \\
(\% \text { of total) }\end{array}$ \\
\hline Biodiversity hotspot (Myers et al., 2000) & $130(48)$ & $5,376(55)$ \\
Critical Ecoregion (Hoekstra et al., 2005) & $144(54)$ & $5,507(56)$ \\
Megadiversity country (Mittermeier, 1997) & $129(48)$ & $4,836(49)$ \\
Located in site with one or more designations & $224(84)$ & $8,372(86)$ \\
\hline
\end{tabular}

of West Africa, the Horn of Africa and the mountains of Central Asia are not.

\section{Political geography of volunteering}

Fig. 1 shows the international distribution of UK conservation volunteers, marking the 33 countries that receive $>100$ volunteers per annum, and the total number of conservation volunteers these countries received in 20062007. On a global scale there is a clear clustering of volunteers into four regions: Southern and East Africa, Central America and the Caribbean, the Andes and the Amazon, and Indonesian Islands.
Together, programmes in these four regions account for $>77 \%$ of all volunteers. South Africa is by far the single most popular destination country (attracting c. 1,873 volunteers in 2006-7), followed by Costa Rica (699) and Indonesia (621). There is observable clustering in the national distribution of volunteers, with the 10 most popular countries accounting for $>50 \%$ of the total.

The political and economic characteristics of the most popular countries $(>100$ volunteers per annum) show some variety. However, in terms of economic development the majority (23 out of 33 ) are middle-income countries (according to the World Bank's classification by GNI per capita; World Bank, 2007a). Australia, New Zealand and

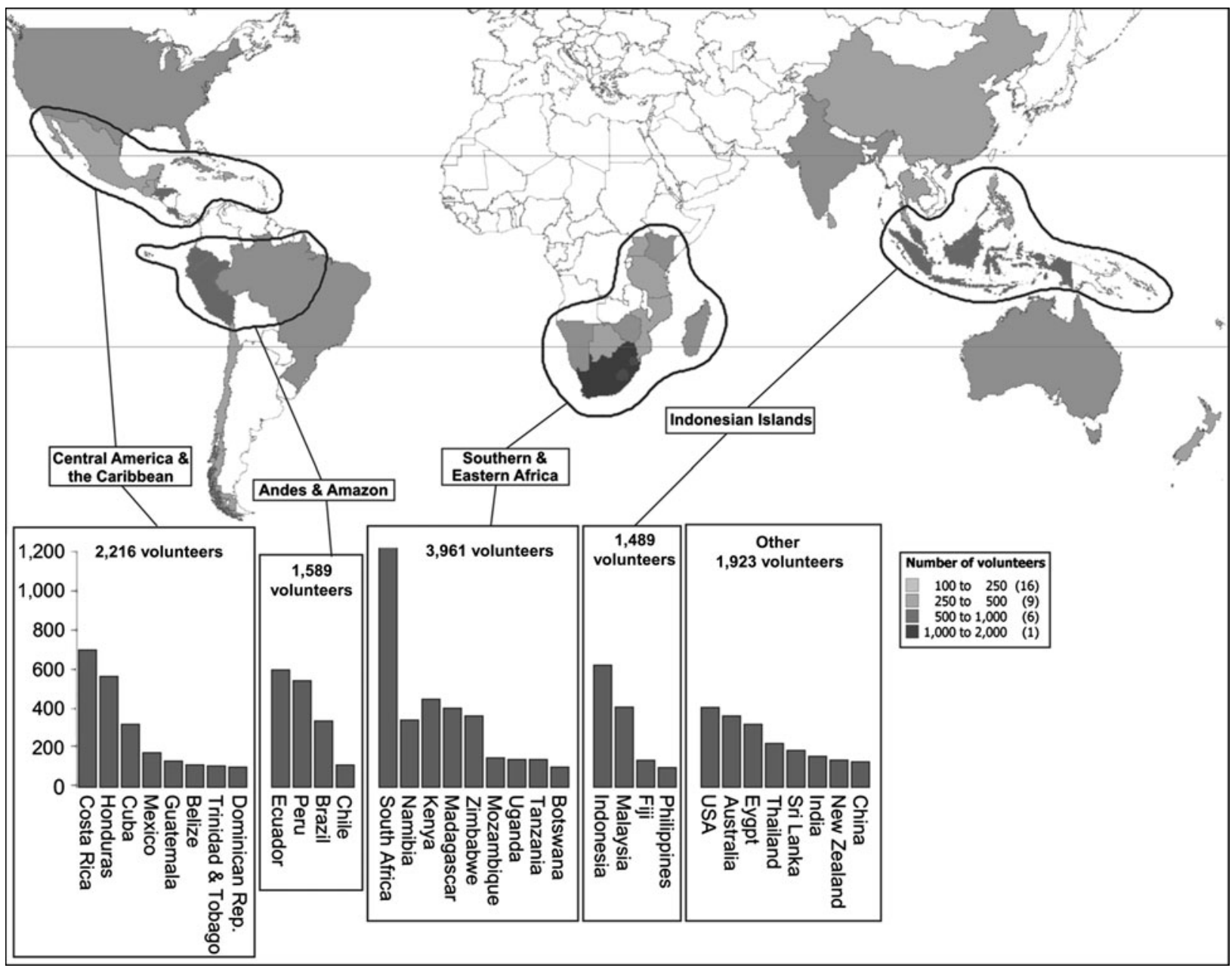

FIG. 1 The global distribution and national totals of conservation volunteer programmes in countries receiving $>100$ volunteers per annum. 
the United States are the three high income exceptions. Low income countries include India and six nations in Southern Africa. The political stability and level of violence in a country are important considerations for organizations hoping to attract volunteers. According to the World Bank's Index of Political Stability and Absence of Violence, the most popular countries for volunteer programmes show some variety, with a surprising number (12 out of 33) located in the lowest quartile. The countries that fare badly on this index include Sri Lanka, the Philippines and Zimbabwe (World Bank, 2007b).

\section{Discussion}

International conservation volunteering represents a significant and growing component of the UK's third sector economy and is responsible for the transfer of funds and labour from high to middle and lower income countries. The GBP 17.27 million annual income of the organizations reviewed in this paper is more than 2.5 times the GBP 7 million annual budget of the UK government's Darwin Initiative (DEFRA, 2007) and is nearly half that of the UK World Wildlife Fund (GBP 40 million; Charities Commission, 2007). However, it is important to consider that the value of labour being provided by volunteers is not costed in these figures. If it were, then the value provided would be much higher. The majority of the time and money spent by volunteers is targeted at threatened species inhabiting zones of global biodiversity importance. However, there are some important gaps in the scope of the sector's environmental concern.

\section{Establishing conservation priorities in the overseas volunteering sector}

To explore the partialities (Fig. 1) it is necessary to understand how the volunteering sector operates, in particular how decisions are made as to which programmes to offer volunteers and thus what is prioritized for conservation. Volunteering organizations play a key role in framing the choices available to consumers but they have to deal with two constraints: the actual availability of projects that can receive volunteers and the real and perceived willingness of fee-paying volunteers to sign up for the projects they propose. When asked how they set priorities, none of the managers interviewed explicitly mentioned any of the global priority templates.

Instead, they explained that prioritization in the sector is conservative, reactive and market-driven. Managers know from past experience which projects work and sell well; they continuously gauge and channel volunteer enthusiasms and then seek to establish or solicit similar ventures. Conservation priorities emerge from the machinations of these negotiations, which are driven by two sets of factors: the availability of possible projects relates to the history and politics of global conservation, while the volunteer market closely reflects the cultural preferences of Western volunteers.

\section{The history and politics of conservation}

British international nature conservation is a political practice, with roots in the long history of uneven development and colonialism, with its associated concerns of hunting, forestry and resource management (MacKenzie, 1988; Brockington, 2002; Adams, 2003; Adams \& Mulligan, 2003). There is a great deal of inertia within conservation and the broader political economy in which it operates such that present practice continues to expresses historic tendencies. This is clearly displayed in the case of volunteering. On the most immediate level, the political and economic conditions of different countries affects where volunteers can and will go. High income countries are expensive to operate in and insurance costs deter many operators. In contrast, low income countries may not have the basic infrastructure to make projects safe and viable.

Organizations have to work hard to reassure their volunteers of the safety of their destinations and the quality of the safety blanket they will provide in case of accident or emergency. Health and safety issues are at the heart of brand development for the main organizations, many of whom have been working to produce a British Safety Standard (BS8848) in the wake of a high profile volunteer death. Nonetheless, when the international perceptions of local political conditions worsen then organizations are often unable to guarantee funding for supported projects. As in Sri Lanka in 2007, long running projects are halted when volunteers and their money are not forthcoming. This has important implications for the scope and sustainability of volunteer-funded conservation projects. Geopolitical imaginaries and realities determine where volunteers will go and what conservation is done. Vast areas of the world, including most of the Middle East and Central and Western Africa are off limits.

Sixty percent of international conservation volunteer programmes, attracting $55 \%$ of British visitors, are located in former British colonies. Several managers explained that this partiality reflects the ease of operating in an English speaking country and the relatively higher levels of institutional and conservation capacity to be found in these countries, often inherited from the colonial period. Together, these result in there being many more projects available for volunteers in such countries.

Thirty-nine percent of volunteers working on speciesspecific programmes focused on organisms that were formerly game animals hunted for sport or profit by British colonials during the 19th century. Here they are engaged in similar practices of observation and safari. Cameras have 
replaced rifles and the trophies are now photographic but the practices persist in ecotourism. This is especially true for programmes in Southern and Eastern Africa, where staged encounters with the big five species in managed game reserves and national parks continue to be a big draw.

Similarly, the preferences expressed towards tropical forests also have a long history. Richard Grove (1996) argues that conservationists' concerns over habitat loss and climate change have their roots in the experience of colonial administrators working in tropical forests. Many perceived these as Edenic places: virgin territories untrammelled by human activity, threatened by indigenous land users and in need of scientific management. The environmental historian William Cronon (1996) has traced the persistence of this imagination (and its associated practices) into the present in his work on the 'trouble with wilderness' in environmental thinking, where wilderness is imagined as a timeless space without people. Tropical forest conservation guided by this approach effaces the environmental history of indigenous inhabitants (Slater, 1996).

These are controversial claims that by no means characterize the practices of all international volunteer projects, many of which work closely with local partners and seek socio-economic development alongside nature conservation. However, critics such as Voluntary Service Overseas and Tourism Concern have recently accused parts of the sector of a new form of colonialism in their modes of operating (VSO, 2007). Reviewing the organizations' marketing materials it is clear that the imagination of tropical forests as pristine Edens still exerts a powerful force on volunteers. These speak of the 'unexplored, remote jungles of Belize' (Trekforce, 2007), or describe Madagascar as 'a tropical Eden threatened with large scale destruction by unsustainable human activities' (Earthwatch, 2007).

\section{The cultural preferences of volunteers}

Existing studies of the motivations of volunteers emphasize the diversity of reasons why people get involved, which include a love of specific places and animals, a desire to 'make a difference', career-development, the accumulation of cultural capital and the pursuit of fun and adventure (Caissie \& Halpenny, 2003; Galley \& Clifton, 2004; Campbell \& Smith, 2006; Low et al., 2007). The challenge for volunteering organizations is to create, harness and direct these ethical energies and enthusiasms. Many of these preferences overlap with those of conservationists but there are some subtle and striking differences. These contrasts and coincidences both enable and constrain volunteer-led conservation programmes and determine which organisms, places and practices they can encompass.

One striking example of the influence of volunteers' cultural preferences is the clear partiality expressed towards charismatic taxa such as turtles, elephants, primates and big cats. The use of such organisms as keystone or flagship species has been the subject of much discussion in the conservation literature, where their role as surrogates and strategic targets has been debated (Simberloff, 1998; Andelman \& Fagan, 2000; Walpole \& Leader-Williams, 2002; Caro et al., 2004). In this context the charisma of a small number of species appears to play a vital role in drawing volunteers into conservation; this non-human charisma (Lorimer, 2007) stimulates their curiosity and ethics.

Reviewing the taxonomy of species prioritized by volunteer programmes in the light of the findings from the interviews, it is clear that charismatic organisms must first be visible, such as the big five, herbivores and cetaceans, but they must also afford either some drama, as with carnivores, or the possibility of interaction, as with primates and turtles. Here an interest in conservation bleeds into a desire for spectacle and a concern for animal welfare and physical contact, both of which have to be addressed by those marketing and managing conservation programmes. This can create problems for the managers of volunteer organizations seeking to do conservation science with volunteers who really only want to get close to and pet animals. This interest in international animal welfare and physical contact appears to be a relatively new phenomena, unprecedented in the history of conservation and worthy of further enquiry.

A broader array of species and ecological processes are encompassed by conservation programmes directed at habitats, and resources raised by organizations for charismatic species can be used to cross-subsidize less popular programmes. It is also important to note that many volunteer organizations channel resources to more cryptic species through other funding sources, such as research grants and corporate fellows. However, the scarcity of volunteer-led programmes dedicated to less visible and accessible groups such as birds, plants, fish and invertebrates raises significant concerns about the efficacy of this model for conserving biodiversity. The need for encounters with charismatic species leaves vast gaps in the range of species that could realistically be targeted by volunteer-led conservation.

In selecting their programmes most volunteers are after a break from the norm in a different environment, involving challenging and entertaining activities. Volunteer conservation programmes have to work within and make use of the places and practices popular with ecotourists. Volunteers are encouraged to travel both to relax and to test and prove themselves. Visions and discourses of challenge and adventure are enrolled by conservation organizations in marketing their programmes and volunteers expect them to be delivered.

There are two types of preferred ecotourist practice that are most clearly expressed in the biogeographical partialities 
mapped in the scope of volunteer conservation. These are safari and diving (both snorkelling and scuba). Twenty-six percent of volunteers working on in situ projects undertook some form of safari, either of the big five species or of whales. Twenty-one percent engaged in snorkelling or scuba-diving. Respectively these help account for the popularity of savannahs (and the big five) and coral reefs as target habitats for conservation. Several managers explained that one of the consequences of this elevation of adventure and the exotic, which also includes beaches and remote islands, is that more mundane places are ignored. Furthermore, others argued that the expectations that volunteers bring to the destinations they visit also affects the type of science that some are willing to undertake. Like a lot of scientific fieldwork, a great deal of conservation research and practice is repetitive and unglamorous and this can deter volunteers.

\section{Conclusions}

International conservation volunteering represents one flexible mechanism for funding global biodiversity conservation beyond economically rich countries and helps transfer much needed money and labour. This sector has grown considerably over the last 20 years and is likely to continue to do so. As other income streams dry up, volunteering will exert increasing influence over the scope and practice of international conservation. I have provided a broad overview of volunteering from the UK that I hope will inspire future work to produce a more complete map of the sector and provide detailed illustrations of its operation.

In its current form international volunteering does target its resources towards species and ecosystems considered to be of global conservation importance. However, this appears to happen more by default than design. There is little in the way of proactive prioritization within the sector, or a shared sense of global purpose. Instead, diverse organizations scrabble for and react to available market opportunities. This trend towards markets can be linked to more general concerns that have been raised about the increasing dependence of conservation on market solutions that have to reconcile conservation with private sector imperatives towards economic growth. Some critics see this trend as evidence of a creeping neo-liberalism in conservation (Igoe \& Brockington, 2008). There are currently many species and areas lacking charisma whose conservation practices are not appealing to volunteers or that inhabit parts of the world too remote or dangerous to be readily commodified for the market and sold to secure sustainable funding. These species and spaces will be offlimits to volunteers and will not be well served by this model. Conservation volunteering is not a panacea for the international effort to save threatened biodiversity.

\section{Acknowledgements}

This research is in collaboration with Professor Sarah Whatmore and was funded by the Economic and Social Research Council. I would like to thank all of the representatives of volunteering organizations who kindly offered their time and opinions during the course of this research.

\section{References}

Adams, W.M. (2003) Against Extinction: The Story of Conservation. Earthscan, London, UK.

Adams, W.M. \& Mulligan, M. (eds) (2002) Decolonizing Conservation: Strategies for Conservation in a Postcolonial Era. Earthscan, London, UK.

Andelman, S. \& FaGan, W. (2000) Umbrellas and flagships: efficient conservation surrogates or expensive mistakes? Proceedings of the National Academy of Sciences of the United States of America, 97, 5954-5959.

Bowker, G. (2004) Time, money and biodiversity. In Global Assemblages (eds A. Ong \& S. Collier), pp. 107-123. Blackwell, Oxford, UK.

BROAD, S. (2003) Living the Thai life: a case study of volunteer tourism at the Gibbon Rehabilitation Project. Tourism Recreation Research, 28, 63-73.

Brockington, D. (2002) Fortress Conservation: The Preservation of the Mkomazi Game Reserve. Indiana University Press, Bloomington, USA.

Brooks, T.M., Mittermeier, R.A., da Fonseca, G.A.B., Gerlach, J., Hoffmann, M., Lamoreux, J.F. et al. (2006) Global biodiversity conservation priorities. Science, 313, 58-61.

Caissie, L.T. \& Halpenny, E.A. (2003) Volunteering for nature: motivations for participating in a biodiversity conservation program. World Leisure Journal, 45, 38-50.

CAmpвell, L. \& S Mith, C. (2006) What makes them pay? Values of volunteer tourists working for sea turtle conservation. Environmental Management, 38, 84-98.

Caro, T., Engilis, Jr, T., Fitzherbert, E. \& Gardner, T. (2004) Preliminary assessment of the flagship species concept at a small scale. Animal Conservation, 7, 63-70.

Charities Commission (2007) The Register of Charities. Http://tiny.cc/ wwfaccounts [accessed 25 September 2007].

Cleary, D. (2006) The questionable effectiveness of science spending by international conservation organizations in the tropics. Conservation Biology, 20, 733-738.

Clifton, J. \& Benson, A. (2006) Planning for sustainable ecotourism: the case for research tourism in developing country destinations. Journal of Sustainable Tourism, 14, 238-254.

Cousins, J. (2007) The role of UK-based conservation tourism operators. Tourism Management, 28, 1020-1030.

Cronon, W. (1996) The trouble with wilderness; or, getting back to the wrong nature. In Uncommon Ground: Rethinking the Human Place in Nature (ed. W. Cronon), pp. 69-9o. W.W. Norton, New York, USA.

DEFRA (2007) The Darwin Initiative: Ninth Annual Report. HMSO, London, UK [http://www.darwin.gov.uk/annual/ 9thAnnualDarwinReport.pdf, accessed 25 September 2007].

EARTHWATCH (2007) 2007 Expedition Guide. Earthwatch Institute, Oxford, UK.

Galley, G. \& Clifton, J. (2004) The motivational and demographic characteristics of research ecotourists: Operation Wallacea volunteers in south-east Sulawesi, Indonesia. Journal of Ecotourism, 3, 69-82. 
Grove, R. (1996) Green Imperialism: Colonial Expansion, Tropical Island Edens and the Origins of Environmentalism, 1600-1860. Cambridge University Press, Cambridge, UK.

Hoekstra, J.M., Boucher, T.M., Ricketts, T.H. \& Roberts, C. (2005) Confronting a biome crisis: global disparities of habitat loss and protection. Ecology Letters, 8, 23-29.

Igoe, J. \& Brockington, D. (2007) Neoliberal conservation: a brief introduction. Conservation and Society, 5, 432-449.

IUCN (2007) 2007 IUCN Red List of Threatened Species. IUCN, Gland, Switzerland. Http://www.iucnredlist.org/ [accessed 25 September 2007].

Lorimer, J. (2007) Nonhuman charisma. Environment and Planning D: Society and Space, 25, 911-932.

Low, N., Butt, S., Ellis Paine, A. \& Davis Smith, J. (2007) Helping Out: A National Survey of Volunteering and Charitable Giving. Office of the Third Sector in the Cabinet Office, London, UK. Http://www.cabinetoffice.gov.uk/thirdsector [accessed 15 September 2007].

MacKenzie, J. (1988) The Empire of Nature: Hunting, Conservation and British Imperialism. Manchester University Press, Manchester, UK.

Mittermeier, R. (1997) Megadiversity. Cemex, Mexico City, Mexico.

Myers, N., Mittermeier, R.A., Mittermeier, C.G., Da Fonseca, G.A.B. \& Kent, J. (2000) Biodiversity hotspots for conservation priorities. Nature, 403, 853-858.

Newman, C., Buesching, C.D. \& Macdonald, D.W. (2003) Validating mammal monitoring methods and assessing the performance of volunteering in wildlife conservation- "Sed quis custodiet ipsos custodies?" Biological Conservation, 133, 189-197.

Rodriguez, J.P., Taber, A.B., Daszak, P., Sukumar, R., Valladares-Padua, C., Padua, S. et al. (2007) Globalization of conservation: a view from the south. Science, 317, 755-756.

Simberloff, D. (1998) Flagships, umbrellas and keystone species: is single-species management passé in the landscape era? Biological Conservation, 83, 247-257.
Slater, C. (1996) Amazonia as Edenic narrative. In Uncommon Ground: Towards Reinventing Nature (ed. W. Cronon), pp. 114-131. W.W. Norton, New York, USA.

Trekforce (2007) Ultimate Gap Year Expeditions. Http://www. trekforceworldwide.com/ultimate_gap_year_expeditions [accessed 10 August 2007].

VSO (Voluntary Service Overseas) (2007) Press Release: Ditch (un)worthy Causes, VSO Advises Gap Year Students. Http:// www.vso.org.uk/news/pressreleases/ditch-unworthy-causes.asp [accessed 9 October 2007].

Walpole, M.J. \& Leader-Williams, N. (2002) Ecotourism and flagship species in conservation. Biodiversity and Conservation, $11,543-547$

Weiler, B. \& Richins, H. (1995) Extreme, extravagant and elite: a profile of ecotourists on Earthwatch expeditions. Tourism Recreation Research, 20, 29-36.

World BANK (2007a) Country Classification. Http://www.worldbank. org/data/countryclass/classgroups.htm [accessed 30 September 2007].

WORLD BANK (2007b) Governance Matters. Http://info.worldbank.org/ governance/wgi2007/ [accessed 30 September 2007].

\section{Appendix}

The appendix for this article is available online at http:// journals.cambridge.org

\section{Biographical sketch}

JAMIE Lorimer is a geographer whose research examines the scope, history, politics and geographies of nature conservation in the UK and Sri Lanka. His most recent project explores the role of volunteers in international nature conservation, with a specific focus on Asian elephant conservation in Sri Lanka. 